Ольга ХАРЛАН,

д. філол. н., проф. Бердянський державний педагогічний університет

\title{
ТОПОГРАФІЯ ЧУЖОГО У ТВОРІ ВІРИ МАРСЬКОЇ «БУРЯ НАД ЛЬВОВОМ»
}

У статті пропонується прочитання роману В. Марської «Буря над Львовом» 3 погляду з'ясування топографії Чужого. Визначаються особливості структурування художнього тексту відповідно до уявлення про множинність і обмеженість місць, де відбуваються події. Звертається увага на амбівалентність розуміння свого і чужого простору, що зумовлено перехрещенням між різними топографічними зонами. Використовуючи поняття «респонзивності» (Б. Вальденфельс), розглядається взаємозалежність невідомого/чужого та знаного/свого.

Ключові слова: топографія Чужого, респонзивність, простір міста, діаспора.

У сучасній філософській, культурологічній, літературознавчій думці все актуальнішою постає категорія Чужого, що презентує одне з основних понять життєвих відчуттів. Проблема Чужого-Іншого в іiі філософськокультурологічній інтерпретації повною мірою заявила про себе наприкінці XX століття, творчо увібравши попередній теоретично-філософський дискурс. Традиційне історико-філософське опрацювання можна знайти ще у Платона, Аристотеля, пізніше в Гегеля. Вже в XX ст. до неї звернулися Е. Гуссерль, М. Гайдеггер, Г.Г. Гадамер, Е. Левінас та ін. Запропоноване у цій статті прочитання повісті Віри Марської «Буря над Львовом» в аспекті 3'ясування топографії Чужого грунтується на праці Б. Вальденфельса [1].

Багато творів, що були написані у міжвоєнне двадцятиліття (19141939), часто є яскравими ілюстраціями існування тріади «Я-Інший-Чужий», намаганням осмислити складність співіснування в одному просторі людей 3 різним сприйняттям та оцінкою світу. До них належить повість Віри Марської «Буря над Львовом» [4]. Твір вийшов друком у 1944 р. в «Українському видавництві» (Краків-Львів), вказаний час написання травень-жовтень 1941 року. Кінцевий варіант опублікований 1952 р. у Філадельфії, де авторка проживала 31949 р. (друга частина написана в лютому 1947 р.). Справжнє прізвище письменниці - Марія Струтинська 
(1897-1984), крім названої повісті, їй належать збірка оповідань «Помилка доктора Варецького» (1964), драматичні твори «Який чистий сніг» (1968) та «Американка» (1973), книга спогадів «Далеке зблизька» (1975), низка статей літературознавчого та публіцистичного характеру, переклади з англійської, французької мов; вона - редактор журналу «Українка» (1937-1939), співредактор літературно-мистецького місячника «Наші дні» (1941-1944) [7, c. $417-418]$.

Дві частини повісті, написані в різні роки і пов'язані з епохальними подіями (початок Другої світової війни, прихід радянської, а потім гітлерівської армії), відповідно мають символічні назви: «Весна восени» і «Сіре й червоне». Події, описані у творі, майже всі відбуваються у Львові, хоч на початку маємо досить цікаві ситуації відпочинку в Косові та подорожі залізницею. За словами М. Струтинської, твір «був конечною вимогою всього мого єства передати людям правду про той страшний режим, що вбиває несуджених ще навіть в'язнів... А втім, почала я писати цю річ (i майже всю першу частин) в бадьорому настрої експериментування з повістюрепортажем (себто сперту на фактах і живих людях), куди вплела любовну фабулу» [3, с. 11]. Як згадувала письменниця, Г. Лужницький назвав ii «письменницею української автентичності» [3, с. 11].

Львів, через переживання мешканців якого сприймаємо події вересня 1939 - червня 1941, у повісті постає як своєрідний Вавилон, місто, в якому силою обставин живуть різні люди, які не завжди розуміють одне одного. $\mathrm{He}$ йдеться про нерозуміння на рівні мови (хоча й мови звучать різні), нерозуміння і навіть несприйняття, здебільшого, національне й ідеологічне. Картину Львова приблизно цього ж періоду проаналізувала Оля Гнатюк у відомій книзі «Відвага і страх»[2]. Розмаїття довоєнного Львова досить повно проілюстровано назвами рубрик у виданні «Leopolis multiplex»: «Lemberg: тоді і тепер»; «Lwów: минуле i пам'ять»; «Львів націоналістичний»; «Львів радянський/російський» [8]. Загалом місто у творі постає своєрідним лабіринтом, у якому кожна частина має своє призначення і 
характеристику, а люди в одному будинку часто більш чужі одне одному, ніж ті, хто живе в різних кінцях міста.

Б. Вальденфельс у праці «Топографія Чужого: студії до феноменології Чужого» висловлює думку, що Чуже має не тільки свої часи, але й свої місця. Осмислюючи появу феномену Чужого, автор вважає, що причиною появи стала зміна в Новий час «розуміння розуму і ролі суб’єкта» [1, с. 6]. Наголошуючи на такому явищі, як наявність певних меж і децентрованості суб’єкта, філософ констатує: «Коротше кажучи, немає жодного світу, в якому ми повністю перебуваємо вдома, і немає жодного суб'єкта, котрий був би господарем у власному домі» [1, с. 7].

Характеризуючи Чуже як топографію чи «місцеопис», Б. Вальденфельс визначає таку його специфіку: топографія пов'язана 3 топосом, простором, який можна розуміти в традиційному його вияві (Аристотелева «Фізика») і в посткартезіанському. Автор звертає увагу і на такий аспект: плюралізація місць у формі Тороі, у місцях виникнення пояснення. Важливим є те, що Tороі охоплює не тільки множинність, мережі місць, але й поняття, що обмежують місце (мости, межі тощо). Таким чином, уможливлюється виникнення гетеротопії (множинність місць), а також атопії (відсутність місця), що вказують на «прірви безмісцевості». Основне припущення вивчення Чужості, за Вальденфельсом, є те, що Чуже первинно слід мислити, виходячи 3 «місць Чужого, як «десь не тут» $\mathrm{i}$ як поза-порядкове (Außerordentliches), яке не має якогось постійного місця й уникає впорядкування (Einordnung). Поділений на місця простір, натомість, слід мислити так, щоб він припускав свої та чужі місця без того, щоб від самого початку звузити чи скасувати відмінність Свого від Чужого» [1, с. 7].

Філософ визначає особливості топографії як способу дослідження: завдяки їй окреслюються шляхи, межові лінії, зв’язки та перехрестя, тобто віддається перевага 3'ясуванню відкритих i обмежених зв’язків перед систематичним закріпленням. Важливою $є$ акцентація на зв’язку 3 географією, котра «у своїй топографічній формі займається охопленням i 
відтворенням форм і предметів місцевості, посилює згадану просторову орієнтацію, яка протидіє однобічній орієнтації на лінеарний історичний час i прогресивний розвиток і через це постійно проблематизує припущення, що чуже є просто тим, що вже або ще є недоступним» [1, с. 8]. Отож, можемо зробити висновок, що розуміння Чужого з погляду топографії як способу дослідження включає в себе відцентрове прочитання тексту, в якому простір обмежений i безмежний, пов’язаний із всечассям (минулим, сучасним i майбутнім), а досвід часу детермінує «занепад певного розуміння та очікування історії»; поняття Свій можливе тільки за умови існування поняття Чужий. У характеристиці Чужого Вальденфельс виділяє три аспекти: місце, володіння, рід, адже Чуже відбувається поза межами свого, належить Іншому, є чужорідним. Серед названих аспектів, на думку філософа, найважливішим є аспект місця.

У повісті Віри Марської головна героїня Оксана Рутецька перебуває в оточенні і своїх, i чужих. Вона переживає три етапи в історії Львова, водночас і три етапи свого життя. Перший - «польський» - упорядкований, 3 усталеним способом життя (робота, помешкання, самотність, відстороненість), що руйнується з початком війни 1 вересня 1939 року та відкриває нове бачення сусідів, співробітників, друзів. Другий «радянський» - несподіваний, непередбачуваний, незрозумілий, жорстокий, який почався з появою нових господарів у Львові, що змушує, знову ж таки, по-новому побачити світ і людей: «3 усіх будинків маяли великі червоні полотнища, з усіх побитих вітрин дивилися яскраво розмальовані, потворновеликі портрети вождів 3 добродушно-всміхненим хитрим обличчям Сталіна в центрі» [4, с. 117]. Третій - «німецький»; у творі епізоди, пов’язані 3 приходом гітлерівського війська до Львова, мають незначний обсяг, але саме вони концентрують увесь страх i макабричність того, що відбувалося напередодні та продовжується тепер (знівечені трупи в’язнів у радянських катівнях і знущання над євреями). 
Авторка структурує твір так, що на кожному 3 цих етапів Оксана знаходиться у становищі, коли іiі життєсвіт ділиться на рідний і чужий. Враховуючи трактування Вальденфельса («Чужий світ не $\epsilon$ просто прикметою моменту» [1, с. 26]), персонажі повісті та Оксана зокрема переживають «чужість» як миттєвий стан і їі тривалу форму. Всі персонажі перебувають в одному географічному світі, але світ цей набуває історичної та культурної варіативності залежно від самоідентифікації персонажа. Так, перебування Оксани у власному помешканні, будинку, місті, навіть на роботі, яке має всі ознаки «своїстості», зі зміною історичних обставин (початком війни, приходом чужих армій) перетворюється в зону «чужості». Її не пускають у будинок жінки, які проживають тут три місяці на противагу Оксаниними трьом рокам, перевіряючи документи тільки через те, що не бачили iï у бомбосховищі; в помешканні турбує двірничка, повідомляючи, що «субльокатор пані мусить зголоситися до копання ровів, як усі мужчини 3 нашого будинку» [4, с. 71]; на роботі чекає розгардіяш і звільнення; Львів теж змінюється і перетворюється не просто на прифронтове місто («Місто жило сьогодні під знаком газової маски. Великі, чорно-жовті й біло-червоні плякати сповіщали про продаж масок у пунктах «Льоп»-у, вже не тільки військові, але й урядовці та робітники місцевих закладів йшли вулицями 3 прип’ятими до пояса масками в сіро-зелених футлярах, ішли й їхали на роверах відділи вояків з газовими масками на обличчях. Літаки скидали метелики 3 поученнями, як поводитися на випадок газової атаки. Сьогодні вночі кінчався німецький ультиматум...» [4, с. 48]), а на місто страху («Збудили їі вибухи. Схопилася з тапчана i, ще вся обважніла від короткого й міцного сну, підійшла до вікна. Люди бігли вулицею, ховалися в будинки. Якийсь хлопчик бігав поперед вікна і свистав у свиставку. Тривога» [4, с. 60]).

Ще більшої трагічності різні топографічні зони «чужості» набувають у другому, «радянському», періоді. Вони розширюють свої межі і набувають інших характеристик через появу нових реалій. Характеристика «чужий світ» 
притаманна більшій частині життєсвіту: робота, місто, будинок, повсякденність. Цікаво, що Б. Вальденфельс, 3'ясовуючи типи чужості, зазначає, що «кожний порядок діяльності або життя підпорядковується специфічним селекціям і виключенням, він утворює певні умови доступності та недоступності, тобто також свойості та чужості» [1, с. 27]. У повісті спостерігаємо, як світ мешканців Львова поступово трансформується у світ Чужого, і ця чужість уже стосується не лише експертності та приналежності до класів Інших, вона охоплює життя загалом.

Іншим та чужим стає простір міста. Одна з характеристик: «Вулиці сірі були від вояцтва, що йшло, вигупуючи важкими, без блиску, чобітьми, хутко проїздили містом блискучі лімузини, розтарахкані вантажники. В місті зникло все їстівне. Крамниці були позачинювані, лиш тут і там відкривали «хлібну», під якою росла в безконечність черга» [4, с. 121]. Невипадково письменниця майже поряд використовує означення «без блиску» (чоботи) i «блискучі» (лімузини): таким чином окреслюється світ, у якому яскравість і «блиск» затьмарюються і затоптуються чужими важкими чобітьми.

Світом, у якому перемежовані своїсть і чужість, стає новостворений музей Івана Франка, в якому працює одна 3 героїнь твору i ледь не влаштовується на роботу Оксана Рутецька. До речі, авторка повісті Марія Струтинська свого часу теж працювала в музеї Івана Франка, тому багато деталей невигадані. Розповідь про музей побудована за принципом протилежностей: розкішна вілла Увієрів, де він розташований, - скромний і ошатний будинок Франка; Тарас Франко, який нібито наділений владою вирішувати долю інших, бо може взяти чи не взяти на роботу, але виявляється що коріння цієї влади у дозволі НКВД; він же, як директор музею, може домовитися про лист до директора в'язниці, але безсилий допомогти брату своєї дружини, засланого в Казахстан, про якого нагадує тільки плач його маленької дитини; трагікомічна у своєму аристократизмі та божевіллі Ольга Франко. 
Якщо повсякденний світ мирного часу і цивільного оточення часто окреслено чужим для персонажів повісті «Буря над Львовом», то світ пенітенціарної системи перетворюється у ворожий. Письменниця подає його крізь сприйняття двох героїнь - Оксани Рутецької та Віри Навринської. Образ Віри багато в чому автобіографічний: Марія Струтинська сама пережила пошуки чоловіка в радянській тюрмі, вистоювання під в'язницею при спробі передати необхідні речі, жах зникнення. Про пережите письменниця залишила спогади [5; 6], в яких у хронологічній послідовності описує весь процес арешту, обшуку, очікування можливості передач, страху загибелі рідних: «Хто може передати сьогодні словами всю напруженість, усю тривожну глибину хвилювань дружини, матері чи сестри арештованого в СССР? Самий спогад про це викликає нервозне тремтіння. Від першої хвилини, коли ніччю з'явилися в нашій хаті озброєні слуги НКВД, аж до останнього моменту, який був у нас моментом жахливого відкриття, що тюрма, де був наш в'язень, змінилася впродовж декількох днів большевицької евакуації Львова у різню людей - увесь цей час пережили ми, як у якомусь жахливому, злому сні, що не хоче скінчитися» [6, с. 311]. Отож, із зображеного випливало, що більшовицька влада відносно людності Львова (та й не тільки) проводила, за Б. Вальденфельсом, «політику чужості», яка «перекреслює усі намагання розуміння та порозуміння» [1, с. 39].

У творі зустрічаємо ще одну цікаву ознаку чужого простору, коли «між різними синхронно та діахронно впорядкованими зонами чужості виникають різноманітні перехрещення» [1, с. 28]. Одне й те ж явище видається і своїм, i чужим, а особа може бути місцевою та іноземною, близькою та чужорідною. Саме такі почуття Оксани передає В. Марська, описуючи зміни, що відбулися в захопленому більшовиками Львові: життя в місті набуває ознак зловісної «умовленої гри», «неухильного ритуалу», коли заарештовують колишніх послів і сенаторів, а водночас у газеті «Вільна Україна» публікують листи відомих людей на підтримку нової влади та із заявами відданості «великому Сталіну». Перехрещення свого й чужого авторка передає через сприйняття 
нових пісень: «Пісню про Сталіна», яку «радіо кричало на всіх перехрестях», коханий Оксани Ярослав Лучківський слухає, стискуючи щелепи, а «вчорашні ліберали» захоплюються і навіть вважають, що іiі мелодія «має щось таке» [4, с. 121]. Найбільш яскраво цю рису передано через сприйняття головної героїні: слухаючи пісню у виконання Оксани Петрусенко, в якій були слова «А тепер ти щаслива і вільна, Україно, вітчизно моя...», вона відчуває подвійні почуття - 3 одного боку, зачарування мелодією, словами, голосом, а з іншого, розуміння неправдивості такого твердження. «Знала, розуміла, що все те - брехня, і слухала тих слів, схвильована, як ніколи при слуханні найпатріотичнішого маршу» [4, с. 121].

У з’ясуванні проблеми Чужого Б. Вальденфельс звертається до поняття «респонзивності», яке $є$ ключовим у його філософії: на виклик чогось невідомого i чужого формується відповідь, а опозиція «домагання відповідь» має в собі респонзивну відмінність, яка проявляється в тому що домагання і відповідь не сходяться в чомусь загальному. В опозиції «свій чужий» як структурі відносин «домагання - відповідь» для логосу «чужого» відкриваються нові можливості. Вони полягають у тому, що домагання Чужого можливе тільки тоді, коли воно відсилає до Свого; в іншому випадку воно не має смислу, бо відсутня структура передрозуміння. Через відсутність передрозуміння виникають нові смисли. За цих умов можна говорити, що маємо справу $з$ досвідом «чужого» як «чужого». У структурі «домагання відповідь» те, що особа відповідає, пов’язане з тим, на що вона відповідає.

У домаганні Чужого Вальденфельс говорить про дві форми: воно спрямоване до когось і водночас на щось, тобто якщо претензія спрямована на особу, це вже є заклик до неї, а отже, момент відповіді починається не мовленням, а тоді, коли особа бачить i чує цей заклик, коли вона повертається на нього. У повісті письменниця фіксує ті моменти, коли «домагання» Чужого переростає в ситуацію зародження етичного ставлення. На початку твору головна героїня часто не відповідає на заклики Чужого, відмовляється їх чути, хоч і розуміє несправедливість, антигуманність того, 
що відбувається у Львові вересня 1939 року, коли руйнується і зникає Польська держава. Вона вважає це навіть справедливим, зважаючи на українсько-польське протистояння. Однак ситуація «домагання» і «відповіді» складається так, що Оксана Рутецька в кінці твору розуміє, що уникнення «відповіді» - це намагання уникнути відповідальності. Те, що вона бачить 27 червня 1941 року, - перебуває поза межами людського, і веде до трагічного висновку: «В жахливій симфонії цього вечора є щось понадлюдське страшне, неохопне розумом. С в ній страшні образи близької смерти поневіряних, що їм кажуть прикидатися собаками, є в ній короткі фуги громів-передвісників катаклітичної загибелі тих, що, хоч носять на поясах Боже ймення, забули Бога. Та все покриває сопух розкладених трупів, прокльони і гнів народу» [4, c. 212]. Отже, Віра Марська через сприйняття героїні приходить до розуміння різниці між Чужим i Ворожим, ухиленням «домагання» Чужого, але неодмінною реакцією на ситуацію ворожості та смерті.

\section{ЛІТЕРАТУРА}

1. Вальденфельс Б. Топографія Чужого: студії до феноменології Чужого / Бернгард Вальденфельс. - К. : ППС - 2002, 2004. - 204 с.

2. Гнатюк О. Відвага і страх : переклад з польської Марти Боянівської / Оля Гнатюк. - К. : Дух і літера, 2015. - 496 с.

3. Інтерв'ю з Марією Струтинською: розмову вела Марта Тарнавська // Наше життя. - 1977. - № 9 (вересень). - С. 10-12.

4. Марська В. Буря над Львовом / В. Марська. - Філядельфія : Вид-во «Київ», 1952. $-214 \mathrm{c}$.

5. Струтинська М. Далеке зблизька / Марія Струтинська. - Вінніпег : Видавнича Спілка «Тризуб», $1975 .-247$ с.

6. Струтинська М. Дружина «ворога народу» / Марія Струтинська // Незалежний культурологічний часопис «ї»: Західна Україна під большевиками. - 2011. - № 66. - С. 310-314.

7. Українська діаспора: літературні постаті, твори, біобібліографічні відомості / Упорядк. В. А. Просалової. - Донецьк : Східний видавничий дім, 2012. - 480 с.

8. Leopolis multiplex. - К. : Грані-T, 2008. -480 c.

\section{REFERENCES}

1. Waldenfels B. Topohrafiia Chuzhoho: studii do fenomenolohii Chuzhoho [Topography of the Alien: phenomenology studies], Kyiv, PPS-2002, 2004, 204 p [In Ukrainian].

2. Hnatiuk O. Vidvaha i strakh [Brave and fear], Kyiv, Dukh i litera, 2015, 496 p [In Ukrainian].

3. Interv'iu z Mariieiu Strutynskoiu: rozmovu vela Marta Tarnavska [Interview with Maria Strutynsky: by Marta Tarnavska], Nashe zhyttia, 1977, No 9 (veresen), pp. 10-12 [In Ukrainian]. 
4. Marska V. Buria nad Lvovom [A storm over Lviv], Philadelfia, Vyd-vo «Kyiv», 1952, 214 p [In Ukrainian].

5. Strutynska $M$. Daleke zblyzka [So far and so near], Winnipeg, Vydavnycha Spilka «Tryzub», 1975, 247 p [In Ukrainian].

6. Strutynska M. Druzhyna «voroha narodu» [Wife of the people's enemy], Nezalezhnyi kulturolohichnyi chasopys «YI»: Zakhidna Ukraina pid bolshevykamy [Independent cultural review "Yi": Western Ukraine under the Bolsheviks], 2011, No. 66, pp. 310-314 [In Ukrainian].

7. Ukrainska diaspora: literaturni postati, tvory, biobibliohrafichni vidomosti [Ukrainian diaspore: literary figures, works, biobibliographic information], Donetsk, Skhidnyi vydavnychyi dim, 2012, $480 \mathrm{p}$ [In Ukrainian].

8. Leopolis multiplex, Kyiv, Hrani-T, 2008, 480 p [In Ukrainian].

\begin{abstract}
АННОТАЦИЯ
Ольга Харлан. Топография Чужого в произведении Веры Марской «Буря над Львовом».

В статье предложено прочтение романа В. Марской «Буря над Львовом» с точки зрения выяснения топографии Чужого. Определяются особенности структурирования художественного текста в соответствии с представлениями о множественности и ограниченности мест, где происходят события. Обращено внимание на амбивалентность понимания своего и чужого пространства, что обусловлено пересечением между разными топографическими зонами. Используя понятие «респонзивности» (Б. Вальденфельс), рассматривается взаимозависимость неизвестного/чужого и известного/своего.

Ключевые слова: топография Чужого, респонзивность, городское пространство, диаспора.
\end{abstract}

\begin{abstract}
Olha Kharlan. Topography of Alien in work Vira Marska "Storm over Lviv".

Philosophy, cultural interpretation problems Alien fully declared itself in the late twentieth century. It was prepared by the previous theoretical and philosophical discourse (Plato, Aristotle, G.W.F Hegel). The preparation of contemporary stage was joined by E. Husserl, M. Heidegger, H. G. Gadamer, E. Levinas and others. Proposed in this article reading of story "Storm over Lviv" by Vira Marska (was published in 1944) is condacted in terms of clarifying the topography of Alien is based on works by B. Waldenfels. In characterization of Alien Waldenfels identifies three aspects: location, ownership, kin, because Alien is out of Native borders, comes out of its belonging to the Other, is alien in origin. Among these aspects, according to the philosopher, the most important aspect is the location.

The characters of the story are experiencing "alienation" as in the immediate situations and its long forms. All the characters are geographically in the same world, but this world get historical and cultural variabilities depending on the identity of the character. So, Oksana stays in her apartment, a house, a city, even at work, which has all the hallmarks of "Native", but changing of historical circumstances (the war, the arrival of foreign armies) turn it into a zone of "otherness".

B. Waldenfels's assumptions of intersections of Alien and Native, call and response as a mode of communication between subject and Alien are also traced baesd V. Marska's text.
\end{abstract}

Key words: topography of alien, response, city space, diaspora 